\title{
Selection of new clones of linalool chemotype from genetic recombination in Lippia alba
}

\author{
Elcio Rodrigo Rufino ( $\left.{ }^{(}\right)$; Walter José Siqueira ( $\left.{ }^{1 *}\right)$; Márcia Ortiz Maio Marques ('); Carlos Augusto \\ Colombo ('); Joaquim Adelino Azevedo Filho ( $\left.{ }^{2}\right)$; Antônio Lúcio Melo Martins ( ${ }^{3}$ ) \\ (') IAC - Centro de Pesquisa e Desenvolvimento de Recursos Genéticos Vegetais, Caixa Postal 28, 13020-902 Campinas (SP), Brasil. \\ (2) APTA - Polo Regional de Desenvolvimento Tecnológico do Agronegócio do Leste Paulista, Caixa Postal 01, 13910-000 Monte \\ Alegre do Sul (SP), Brasil. \\ (3) APTA - Polo Regional de Desenvolvimento Tecnológico do Agronegócio do Centro-Norte, Caixa Postal 24, 15830-000 Pindorama \\ (SP), Brasil. \\ (*) Corresponding author: walterjs@iac.sp.gov.br
}

Received: Jul. 21, 2017; Accepted: Jan. 31, 2012

\begin{abstract}
The aromatic and medicinal species Lippia alba is vigorous and rugged native to the South America (Atlantic Rainforest). Because it is an allogamous and self-incompatible species, natural populations have high morphological and chemical variability. This work had as objective to conduct a preliminary screening to identify new promising clones from a novel (recombinant) base population of Lippia alba with regard to its agronomic and phytochemical traits, using the linalool oil or chemotype as model. The two superior linalool clones, obtained by collection, were used as controls. Traits evaluated included: dry mass of leaves (DML), oil yield percentage (EOY\%), oil production per plant (OP), and linalool percentage (LN\%). Forty linalool chemotype clones were evaluated in three experiments, in a random block design with four replicates and four cuttings (clones) per plot. Besides means comparisons, multivariate analysis was used in order to aid in the preliminary selection of clones. There were positive correlations from moderate to strong for DML vs. EOY\%, OP vs. EOY\% and DML vs. OP. Linalool clones superior or similar to both controls were identified for the DML, EOY\%, OP, and LN\% traits (univariate analyses), aimed at further validating experimentation. Five distinct groups were defined in the cluster analysis (UPGMA), each containing subgroups as well.
\end{abstract}

Key words: Verbenaceae, oil linalool, genetic divergence, clone selection, plant breeding.

\section{Seleção de novos clones de quimiotipo linalol em Lippia alba oriundos de recombinação genética}

\section{Resumo}

A espécie Lippia alba, aromática e medicinal, é nativa da América do Sul (Mata Atlântica) e possui muito vigor e rusticidade. Por ser espécie alógama e autoincompatível, as populações naturais possuem elevada variabilidade morfológica e química. O presente trabalho teve por objetivo realizar uma triagem prévia para identificação de novos clones promissores, oriundos de uma população-base inédita (recombinante) de Lippia alba quanto às características agronômicas e fitoquímicas, tendo como modelo o óleo ou quimiotipo linalol. Como controles, utilizaram-se os dois melhores clones linalol, obtidos por coleta. As características avaliadas foram: massa seca de folhas (MSF), rendimento de óleo (RD\%), produção de óleo por planta em g (PO) e porcentagem de linalol (LN\%). Foram avaliados 40 clones de quimiotipo linalol em três experimentos em delineamento de blocos ao acaso com quatro repetições e quatro estacas (clones) por parcela. Todos os dados foram obtidos com médias por planta. As médias foram testadas por Scott e Knott a 5\% de probabilidade. Para auxiliar na seleção prévia de clones também foi empregada a análise multivariada. Houve correlações positivas moderadas a fortes para MSF x RD\%, PO x RD\% and MSF x PO. Para as características MSF, RD\%, PO e LN\% (análises univariadas) identificaram-se clones linalol superiores e semelhantes aos dois controles visando às experimentações posteriores de validação. Na análise de agrupamentos (UPGMA) foram definidos cinco grupos distintos e cada um deles também com subgrupos.

Palavras-chave: Verbenaceae, óleo linalol, divergência genética, seleção de clones, melhoramento de plantas.

\section{INTRODUCTION}

Due to a wide range of edaphoclimatic conditions, Brazil has been considered as one of the most important biological diversity centers of the world.
Nowadays, the herbal medicine market is expanding in Brazil. It represents the incoming of US\$ 160 millions, what means the increase of $15 \%$ per year, while the allopathic medicine reaches only $4 \%$ (CARvalHo et al., 2008). 
The species Lippia alba, which belongs to the Verbenaceae family and has Brazil as one of its main countries of origin, stands out among the South American flora (BRANDÃo et al., 2007). This family has about 200 species in three diversity centers, of which Brazil is the largest, with 111 species (AtTi-Serafini et al., 2002; SiLva et al., 2006). Reproduction is by allogamy, with inflorescences of hermaphrodite flowers, but marked by self-incompatibility and irregular germination of seeds. $L$. alba shows variability for several morphoagronomic traits (Rufino et al., 2010), including its essential oils, which are products of secondary metabolism. Essential oil is a product obtained from vegetable raw material either by distillation with water or steam, leaves, seeds, flowers or by a mechanical process or by dry distillation.

L. alba preparations have been used in home medicine, for the relief of several illnesses: stomach aches, constipations, colds and spasms (Di StASI et al., 2002, BraGa et al., 2005), as well as sedative and hypertension relieves (Gazola et al., 2004; Braga et al., 2005). Leaves and roots are the most used in several ways: infusions, baths, and alcoholics extracts (Julião et al., 2003; SCARpa, 2004). Among the several chemotypes occurring in the species, linalool, an open chain monoterpenic alcohol has been detected, able to give rise to isomers (Silva et al., 2003). So, a wide range of uses can be prescribed: antiseptic (Simóes and Spitzer, 2003), sedative and insecticides (Silva et al., 2003; Luz et al., 2009) as well as in formulations of cosmetics and perfumes (BozIN et al., 2006; Martins et al., 2010).

Because it is used in the composition of perfum (Chanel n. ${ }^{\circ}$ 5, commercially launched in 1921), linalool as a raw material is being obtained by extractivism, contributing toward the extinction of Aniba rosaeodora (rosewood), a hardwood tree from the Amazon region, whose bark abundantly produces the oil. Therefore, starting from a broad-base genetic population (recombination between five different chemotypes) of $L$. alba, obtained at Instituto Agronômico, State of Sáo Paulo, 40 new linalool chemotype clones were identified. These clones were evaluated for several morphological, agronomic, and phytochemical traits in three experiments, as compared to the best linalool clones used as controls, obtained by sampling (ҮАмамото et al., 2008).

\section{MATERIAL AND METHODS}

A base population of 296 individuals was obtained at Instituto Agronômico (IAC), Campinas, State of São Paulo, in January 2006, by means of open-pollinated recombination of 20 clones, representing five chemotypes (linalool, limonene/carvone, citral, myrcene/camphor, and myrcene). The plants were maintained on a commercial organic substrate for vegetables (HT) in $10 \mathrm{~L}$ pots under drip irrigation. When the adult stage was reached, plants of the linalool chemotype were identified by olfaction (three evaluators), since these are easily recognizable. Thirty-eight new linalool clones from that population (more two controls) were then identified and cuttings were collected to conduct three experiments, two at Centro Experimental de Campinas (CEC/IAC) and one at Polo Regional de Desenvolvimento do Leste Paulista, in Monte Alegre do Sul, SP. The two best clones (IAC2 and IAC8) of the linalool chemotype studied by Үамамото et al. (2008) were collected and used as controls. The cuttings from the forty clones measured $20 \mathrm{~cm}$ on average, with four alternate nodes (two opposed buds per node) and a diameter of approximately $1.0 \mathrm{~cm}$; cuttings were maintained in a greenhouse (02/22/2007) on HT organic substrate for sprouting and rooting.

A random block experimental design was adopted, with four replicates and four cuttings per plot, spaced at $1.0 \times 0.80 \mathrm{~m}$.

Two experiments were installed in Campinas, SP,

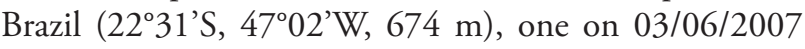
(EP1), in a medium fertility area, $\mathrm{pH} 5.3$, with a base saturation level of $65.0 \%$, while the other (EP2) was installed on 05/17/2007 in a more fertile area, previously cultivated with tomato, $\mathrm{pH} 6.4$, and $89.9 \%$ of base saturation level. The third experiment (EP3), was installed on 06/02/2007 at Polo Regional do Leste Paulista (22²4'S, $46^{\circ} 24^{\prime} \mathrm{W}, 820 \mathrm{~m}$ ), in the city of Monte Alegre do Sul; the region has lower temperatures, with fertility equivalent to the Campinas site, $\mathrm{pH} 5.4$, and $62.0 \%$ of base saturation level. The plants were drip irrigated with a flow of $2.4 \mathrm{~L} \mathrm{~h}^{-1}$. Traits were evaluated in the two central plants and means were obtained per plant.

During growth the plants were tutored to prevent them from touching the ground and becoming rooted, since this is a colonizing species. The above-ground part of both central plants was harvested separately per experiment, harvested between 01/08 to 08/21/2007 (EP1), $24 / 09$ to $10 / 29 / 2007$ (EP2) and $05 / 11$ to $11 / 26 / 2007$ (EP3), covering the period of spring. At harvest, the plants were evaluated for the following morphological, agronomic, and phytochemical traits:

a) Dry mass of leaves (DML) in $\mathrm{g} \mathrm{pl}^{-1}-$ after removing the leaves from all branches collected in both plants of the plot, the leaves were distributed onto newspaper sheets in rooms maintained at room temperature for gradual drying until constant weight to obtain DML and, later, to extract the essential oil and obtain yield (SAntos and InNecco, 2003).

b) Essential oil yield (EOY\%) - this trait was only evaluated in the 30 most productive clones $(28$ recombinants + IAC) for DML. Dry leaves were macerated and placed in $2.0 \mathrm{~L}$ volumetric flasks containing $1.0 \mathrm{~L}$ distilled water; extraction was performed for 1 hour 
and 30 minutes. After that period, the essential oil was collected into previously weighed glass flasks with glass stoppers and placed in freezer in order to later obtain yield and inject into a gas chromatograph attached to a mass spectrometer to get readings for the essential oil components. Since this trait has high experimental precision (SANTOS and InNECCO, 2003), and to facilitate laboratory operations, we chose to obtain yield values in only two blocks selected at random per experiment.

After all extractions were performed, the water present in the flasks was removed with a micro pipet $(200 \mathrm{~mL})$, and then the essential oil was weighed in a semi-analytical balance $(0.01 \mathrm{mg})$. EOY\% was obtained by the $\mathrm{g} \mathrm{g}^{-1}$ ratio between mass of oil and mass of dry leaves $\times 100$.

c) Oil production per plant (OPP) in $\mathrm{g}$ - obtained by multiplying DML by EOY $\times 100^{-1}$.

d) Linalool percentage in the essential oil (LN\%) - for phytochemical analysis purposes, the five best clones for yield and oil production per plant were selected, in addition to both controls, as follows: 166, 201, 251, 280, 288, IAC 2 and IAC 8. Only the major compound linalool, present in the essential oil, was evaluated statistically.

The separation and quantification (method of normalization area) of the compounds was performed by gas chromatography equipment with detector flame ionization (GC-FID, Shimadzu GC-2010), capillary column DB-5 (J \& W Scientific), $30.0 \mathrm{~mm} x$ $0.25 \mathrm{~mm} \times 0.25 \mu \mathrm{m}$. The identification of substances was performed in chromatograph gas coupled to mass spectrometer (GC-MS, Shimadzu QP-5000), operating in electron impact $(70 \mathrm{eV}), \mathrm{OV}-5$ capillary colu$\mathrm{mn}$ (Ohio Valley Specialty Chemical, Inc.), $30.0 \mathrm{~mm}$ $\times 0.25 \mathrm{~mm} \times 0.25 \mu \mathrm{m}$. The conditions of analysis in the GC-FID were as follows: injector: $220^{\circ} \mathrm{C}$, detector: $230^{\circ} \mathrm{C}$, carrier gas: helium with a flow rate

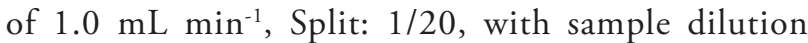
$1 \mu \mathrm{L}$ of oil to $1 \mathrm{~mL}$ of ethyl acetate, the injection volume was $1 \mu \mathrm{L}$ and the temperature program was $50^{\circ} \mathrm{C}-165^{\circ} \mathrm{C}, 4^{\circ} \mathrm{C} \min ^{-1}, 165^{\circ} \mathrm{C}-220^{\circ} \mathrm{C}, 10^{\circ} \mathrm{C} \mathrm{min}^{-1}$. Analysis in the conditions of GC-MS: injector: $220^{\circ} \mathrm{C}$, detector: $230^{\circ} \mathrm{C}$, carrier gas: helium with a flow rate of $1.0 \mathrm{~mL} \mathrm{~min}{ }^{-1}$ Split $1 / 20$. The dilution of the sample was $1 \mu \mathrm{L}$ of oil to $1 \mathrm{~mL}$ of ethyl acetate, with $1 \mu \mathrm{L}$ injection volume and the temperature program was: $60{ }^{\circ} \mathrm{C}-240{ }^{\circ} \mathrm{C}, 3^{\circ} \mathrm{C} \mathrm{min}^{-1}$.

The identification of substances was performed by comparing their mass spectros with the database system GC-MS (62 NIST. lib.) And authentic standard of linalool (Sigma Aldrich, 95\%) and the linear retention index (ADAms, 1995). The retention rates of the substances were obtained by co-injection of the essential oil with a standard mixture of hydrocarbons $\left(\mathrm{C}_{9}-\mathrm{C}_{24}\right)$, applying the equation Van Den Dool and Kratz (1963).

Scott and Knott's test at 5\% (Sсотт and Knott, 1974) was used for all traits evaluated in the clone mean contrasts, which is less robust but without ambiguities, with well defined contrast classes (ZimmermanN, 2004; CRUZ, 2005). The single variation sources were tested against the clones $\times$ experiments interaction whenever the interaction was significant at $5 \%$ by the $\mathrm{F}$ test. As to the means comparison test, in case of interaction, the discussions on clone performance were prioritized for each experiment to the detriment of the joint analysis of means (Gomes, 1966). On the other hand, it must be pointed out that in the present work, the aim was not to make a final recommendation of clones or cultivars for planting, in view of the large number of treatments, but to select new, promising, and therefore more competitive linalool clones, with performance near or superior to the controls obtained by collection (ҮАмамото et al., 2008), for later validating experimentation. Therefore, the means of the joint analysis of data were also taken into account even when interactions occurred.

Thus, in order to identify some superior genotypes in this preliminary screening, involving a large number of clones from recombination for later experimentation, selection was oriented toward both means comparison tests in a pairwise fashion, as well as towards their situation in relation to both controls (IAC 2 and IAC 8).

Pearson's correlations test (Morrison, 1976) was applied to determine the linear associations between the various traits evaluated, since early selection could be applied to aid genetic breeding, especially in relation to phytochemical traits, which are time-consuming, costly, and hard to obtain. Significance of correlations was checked by $t$ test at $1 \%$ and $5 \%$. High number of treatments and high degrees of freedom as well, have caused significant correlations valus ( $t$ test) even in the those of low values. Therefore, Shimakura and Ribeiro JUNior (2007) criterion was applied, with classes separated according to the magnitudes of correlations obtained, as follows: $0.0-0.19$ very weak; de $0.20-0.39$ weak; de $0.40-0.69$ intermediate; $0.70-0.89$ strong and $0.90-1.00$ very strong.

The following programs were used in the univariate statistical analyses and Pearson correlations: SANEST (SANEST Software Program - Machado and Zonta, 1995) and GENES (Cruz, 2001).

In order to supplement the identification of new linalool clones among the 38 analyzed by univariate statistics character by character, two multivariate analysis were employed as well: cluster analysis (dendrogram) and principal components analysis (PCA). It is important to point out that only clones that participated in essential oil extraction (30 clones), therefore those that possessed 
phytochemical traits, were evaluated in the multivariate analyses. The GENES software was used in both multivariate analysis and the data input matrix was prepared from the overall means of the three experiments.

In the cluster analysis, the genetic divergence between genotypes was quantified based on the standardized Euclidean distance, as a dissimilarity measure. Based on the distance established between individuals, the genotypes were grouped using the UPGMA method. The clusters were thus established in bidimensional graphical form via PCA, using the Statistica software (STATSOFT INC. 1999).

\section{RESULTS AND DISCUSSION}

\section{Pearson Correlations (r)}

The results obtained for the simple correlations between traits essential oil yield (EOY\%), oil production per plant (OPP), dry mass of leaves (DML) in L. alba as follows: EOY\% x OPP: 0.506; EOY\% x DML: 0.104 and OPP x DML: 0.868 . The correlation between EOY\% $\times$ OPP (0.506) was highly significant by the $t$ test, but fell into the moderate class. However, EOY\% did not show correlation with DML. In this respect, it seems that the occurrence of moderate correlation between EOY $\times$ OPP could be exclusively due to dry mass total per plant, since OPP was calculated by the product between EOY and DML.

\section{Single and joint variance analyses}

The DML trait can be considered more relevant to increase total oils and linalool yield during breeding for the selection of new clones. From table 1, facilitating the selection of more productive clones, even at high $\mathrm{CV}_{\mathrm{E}} \%$ values (26.0 to 32.5). SANGalli et al. (2004) also found low experimental precision values for DML in studies on fertilization with organic residues and nitrogen. MARCO et al. (2006) also obtained a high coefficient of experimental variation working with different Citronella Java (Cymbopogon winterianus Jowitt) row spacing and harvesting seasons.

In EP1, clone 238 differed from both controls. Clone 280 was again the best in Ep2 and EP3, significantly differing from both controls at 5\% (EP3). The clones selected for DML were as follows: 280, 238, 219, 199, 251, 201, 241, 144, and 288.

The EOY\% levels of superior clones found in this work are within the range obtained by ҮАмАмото et al. (2008), whose lowest EOY\% value observed in ten experiments was 0.93 . CV\% values were low, varying between
$8.5 \%$ and $9.5 \%$ and revealing good experimental control (Table 2). The clones selected for this trait with values near those obtained in the controls were: $288,166,251$, 80, 280, 70, 49, 201, 144, and 137.

There was broad variation in OPP contents among the three experiments (Table 3). EP1 was considered an unfavorable environment (soil compaction); for this reason, it had the lowest OPP mean $\left(0.096 \mathrm{~g} \mathrm{pl}^{-1}\right)$. Ep3 ranked second, at $0.396 \mathrm{~g} \mathrm{pl}^{-1}$, while the best experiment area was EP2, with $0.647 \mathrm{~g} \mathrm{pl}^{-1}$. Clone 280 stood out in $\mathrm{EP} 2$, statistically differing from the other clones evaluated, with a mean production of $2.36 \mathrm{~g}$.

In EP3, the means were intermediate between EP1 and EP2; however, clone 280 again differed statistically from the other genotypes evaluated, with an average of $1.63 \mathrm{~g}$. The clones selected for OPP considering their mean (joint) behavior and homogeneity in the three experiments were: 280, 251, 166, 288, 201, and 70.

Based on the analysis of the phytochemical profile of the five best clones for DML, EOY\%, and OPP, in addition to both controls, significant mean variations in linalool contents were detected among the clones. Since no genotype $\times$ environment interactions occurred, the discussions focused only the means obtained in the joint ANOVA for all experiments.

The coefficient of variation for this analysis was very low, which allowed good separation of clones via Tukey's test. It was seen that clones 201 and 288 did not statistically differ from each other; however, they were statistically superior to both controls used, demonstrating the genetic potential of the species to be exploited for the selection of new clones by means of genetic recombination. TAVAREs et al. (2005) analyzed the essential oil chemical composition of three Lippia alba chemotypes and identified linalool contents of $74.0 \%$ during the vegetative stage and $60.1 \%$ during flowering, which are much smaller values than those found in this work.

The best two clones in this study for $\mathrm{LN} \%$ produced, on the average of three Exps, $85.3 \%$ and $84.8 \%$, respectively, for clones 201 and 288 , and were statistically superior to both controls. In turn, clone 280 showed statistical similarity with the controls, with LN\% values of -80.0 (Table 4). It can be therefore concluded that gains in linalool production and total essential oils can be obtained by direct selection for these traits per se, but the highest increases will be achieved by indirect selection, i.e., selecting for DML.

\section{Multivariate analyses}

The thirty-clone analysis (28 recombinants and 2 controls) generated the dendrogram shown in figure 1, forming five distinct groups, including subgroups, 
according to the standardized Euclidean distance. Since the objective of multivariate analysis was to observe which recombinating clones would be more similar to both controls, IAC2 and IAC8, an attempt was made to identify the group or subgroup that would contain those clones. Thus, it was seen that the fourth group consisted of recombinating clones together with the collected clones (controls), including 129, 219, T2 (IAC 2), and T1 (IAC 8). The most similar genotypes within this group were 219 and T2 (IAC 2). The clone with the greatest dissimilarity within the group was number 129 . These genotypes had means very close to the controls for some of the traits evaluated. Special emphasis is placed on clone 280 , whose superiority had already been statistically detected for some individual traits. In the multivariate cluster analysis, this clone formed the fifth and last group by itself, with $100 \%$ dissimilarity from all clones evaluated (Figures 1, 2 and 3).

Table 1. Evaluation of dry mass of leaves (DML) in 38 experimental clones and two controls in Lippia alba

\begin{tabular}{|c|c|c|c|c|c|c|c|c|c|c|c|c|c|c|}
\hline \multicolumn{15}{|c|}{ Clones and experiments* } \\
\hline$C L$ & EP 1 & \multicolumn{2}{|c|}{ SK } & \multirow{2}{*}{$\begin{array}{c}\text { CL } \\
280\end{array}$} & \multirow{2}{*}{$\begin{array}{c}\text { EP } 2 \\
163.00\end{array}$} & \multicolumn{2}{|c|}{ SK } & \multirow{2}{*}{$\begin{array}{c}\mathrm{CL} \\
280\end{array}$} & \multirow{2}{*}{$\begin{array}{c}\text { EP 3 } \\
126.67\end{array}$} & \multicolumn{2}{|c|}{ SK } & \multirow{2}{*}{$\begin{array}{c}\text { CL } \\
280\end{array}$} & \multirow{2}{*}{$\begin{array}{c}\text { CJ } \\
102.72\end{array}$} & \multirow{2}{*}{$\begin{array}{l}\text { SK } \\
\mathrm{A}\end{array}$} \\
\hline 238 & 31.50 & B & $\mathrm{a}$ & & & A & $\mathrm{a}$ & & & A & $\mathrm{a}$ & & & \\
\hline IAC 8 & 24.13 & $C$ & $b$ & IAC 2 & 125.63 & A & $b$ & IAC 8 & 73.50 & B & $b$ & IAC 8 & 70.42 & B \\
\hline 219 & 19.00 & $\mathrm{~B}$ & c & IAC 8 & 113.63 & A & $b$ & 199 & 68.63 & A & $b$ & IAC 2 & 69.51 & B \\
\hline 280 & 18.50 & B & c & 219 & 89.75 & A & c & IAC 2 & 65.17 & B & $b$ & 238 & 58.13 & B \\
\hline IAC 2 & 17.75 & C & c & 238 & 78.63 & A & d & 238 & 64.25 & $A$ & $b$ & 219 & 57.21 & B \\
\hline 261 & 16.50 & B & c & 129 & 74.75 & A & d & 219 & 62.88 & $A B$ & b & 199 & 46.13 & C \\
\hline 144 & 16.50 & B & c & 201 & 72.00 & A & d & 251 & 42.38 & $A B$ & c & 251 & 41.83 & C \\
\hline 199 & 16.13 & B & c & 251 & 70.13 & A & d & 70 & 42.25 & A & c & 109 & 40.38 & C \\
\hline 201 & 15.25 & B & c & 137 & 68.50 & A & d & 109 & 41.50 & B & c & 129 & 39.00 & C \\
\hline 147 & 14.63 & B & c & 109 & 65.50 & A & d & 241 & 37.25 & $A B$ & c & 201 & 38.25 & C \\
\hline 109 & 14.13 & C & c & 135 & 64.88 & A & $d$ & 129 & 36.75 & B & c & 241 & 37.88 & C \\
\hline 241 & 13.75 & B & c & 241 & 62.63 & A & d & 288 & 36.13 & $A B$ & c & 288 & 35.46 & C \\
\hline 251 & 13.00 & B & c & 166 & 62.25 & A & d & 146 & 34.00 & A & c & 70 & 34.83 & C \\
\hline 135 & 12.25 & B & $d$ & 128 & 61.75 & A & d & 147 & 33.83 & $A B$ & c & 166 & 34.63 & C \\
\hline 9 & 11.25 & B & $d$ & 288 & 60.63 & A & d & 166 & 33.25 & B & c & 135 & 34.60 & C \\
\hline 70 & 11.00 & B & d & 144 & 60.00 & A & d & 44 & 31.63 & A & d & 137 & 34.21 & C \\
\hline 120 & 9.75 & C & $d$ & 9 & 59.63 & A & $d$ & 212 & 28.88 & $A B$ & $d$ & 147 & 32.32 & C \\
\hline 288 & 9.63 & B & d & 199 & 53.63 & A & $d$ & 235 & 27.50 & $A B$ & d & 128 & 30.33 & C \\
\hline 47 & 9.50 & A & d & 31 & 52.75 & A & d & 201 & 27.50 & B & d & 144 & 30.11 & C \\
\hline 43 & 8.88 & B & d & 80 & 51.63 & A & d & 213 & 27.38 & A & d & 44 & 29.33 & C \\
\hline 166 & 8.38 & C & $d$ & 70 & 51.25 & A & d & 137 & 27.13 & B & $d$ & 9 & 29.24 & C \\
\hline 235 & 8.13 & B & d & 44 & 50.13 & A & d & 135 & 26.67 & B & d & 146 & 27.67 & C \\
\hline 136 & 7.75 & B & $d$ & 147 & 48.50 & A & $d$ & 2 & 26.17 & B & d & 120 & 26.19 & C \\
\hline 212 & 7.63 & B & $d$ & 120 & 45.00 & A & e & 27 & 25.25 & A & d & 235 & 25.63 & C \\
\hline 213 & 7.63 & B & $d$ & 146 & 42.88 & A & e & 128 & 24.13 & B & $d$ & 213 & 25.54 & C \\
\hline 80 & 7.50 & B & $d$ & 32 & 42.75 & A & e & 120 & 23.83 & B & $d$ & 32 & 24.29 & C \\
\hline 32 & 7.50 & B & d & 213 & 41.63 & A & e & 32 & 22.63 & $A B$ & e & 80 & 24.04 & C \\
\hline 49 & 7.25 & B & $d$ & 235 & 41.25 & A & e & 261 & 21.75 & $A B$ & e & 212 & 23.75 & C \\
\hline 137 & 7.00 & B & $d$ & 196 & 41.25 & A & e & 22 & 19.83 & A & e & 31 & 23.72 & C \\
\hline 22 & 6.50 & B & $d$ & 216 & 39.25 & A & e & 49 & 18.75 & $A B$ & e & 261 & 22.92 & C \\
\hline 44 & 6.25 & B & $d$ & 172 & 36.38 & A & e & 216 & 17.67 & $B$ & e & 2 & 21.76 & C \\
\hline 146 & 6.13 & B & d & 212 & 34.75 & A & e & 9 & 16.83 & $B$ & e & 216 & 20.56 & C \\
\hline 2 & 5.63 & C & d & 136 & 33.63 & A & e & 144 & 13.83 & B & e & 196 & 18.54 & C \\
\hline 196 & 5.63 & B & $d$ & 2 & 33.50 & A & e & 31 & 13.17 & B & e & 49 & 18.33 & C \\
\hline 129 & 5.50 & C & $d$ & 261 & 30.50 & A & e & 80 & 13.00 & B & e & 27 & 17.92 & C \\
\hline 31 & 5.25 & B & $d$ & 47 & 29.00 & A & e & 43 & 12.00 & $A B$ & e & 136 & 17.38 & C \\
\hline 128 & 5.13 & C & $d$ & 49 & 29.00 & A & e & 47 & 10.75 & A & e & 172 & 16.61 & C \\
\hline 216 & 4.75 & B & d & 27 & 24.50 & A & e & 136 & 10.75 & B & e & 22 & 16.57 & C \\
\hline 172 & 4.13 & B & $d$ & 22 & 23.38 & A & e & 172 & 9.33 & B & e & 47 & 16.42 & C \\
\hline 27 & 4.00 & B & d & 43 & 14.88 & A & e & 196 & 8.75 & B & e & 43 & 11.92 & C \\
\hline Means & 10.77 & C & & & 56.12 & A & & & 32.59 & B & & & 33.16 & \\
\hline CV(\%) & 32.24 & & & & 24.78 & & & & 26.53 & & & & 29.15 & \\
\hline
\end{tabular}

Means followed by the same minuscule letter (vertical) do not differ significantly between clones by Scott and Knott test (SK) at $5 \%$ of probability.

Means followed by the same capital letter (horizontal) do not significantly differ between experiments by Scott and Knott test (SK) at $5 \%$ of probability.

${ }^{*} \mathrm{CL}=$ clones: $\mathrm{CJ}=$ joint analysis of experiments: $\mathrm{CV}(\%)=$ environmental coefficient of variation: $\mathrm{EP} 1=$ first experiment: $\mathrm{EP} 2=$ second experiment: $\mathrm{EP} 3=$ third experiment. 
According to the literature, the most important application of cluster methods in multivariate analyses is the identification of divergent parents for future hybridizations, in order to exploit heterotic gene effects. In the present work, the aim was exactly the opposite, i.e., this type of analysis is to be used by the breeder as an additional strategy for the preliminary identification of clusters of similar (less divergent) individuals or divergent individuals that are superior in relation to both controls used in this study.

\section{Principal components analyses}

Using principal components analyses, the distribution and formation of groups of individuals very similar to those shown in the cluster analysis was visualized on a bidimensional plane. The values absorbed for each component were 53.7; 15.3; and 9.5, respectively, for PCA 1, PCA 2, and PCA 3 (Figures 2 and 3). Together, the first two components absorbed $69 \%$ of the observed variation. In PCA1, among the variables that most influenced the distribution of clones, DML were prominent, with eigenvectors of 0.945 (Figure 2). By analyzing the spatial planes for PCA1 and PCA2, the selected clones (with redundancies in accordance with the distances and principal components involved) were as follows: 280 as the only clone with divergence higher than the controls, and the others in the same group, 238, 219, 70, 251, 199, 129 and 109 (PCA1) and 238, 219, 70, 109, 129, and 137 (PCA2). In PCA3, the selected clones were 280, 70, 109, 129, and 137 (Figure 3). Ten new linalool clones $(70,109,199,201,219,238,241,251,280$ and 288) were selected using through three different analysis approaches.

Table 2. Evaluation of essential oil yield (EOY\%) in 28 experimental clones and two controls in Lippia alba

\begin{tabular}{|c|c|c|c|c|c|c|c|c|c|c|c|c|c|c|}
\hline \multicolumn{15}{|c|}{ Clones and experiments* } \\
\hline $\mathrm{CL}$ & EP 1 & \multicolumn{2}{|c|}{ SK } & \multirow{2}{*}{$\begin{array}{c}\text { CL } \\
166\end{array}$} & \multirow{2}{*}{$\begin{array}{l}\text { EP 2 } \\
1.60\end{array}$} & \multicolumn{2}{|c|}{ SK } & \multirow{2}{*}{$\begin{array}{c}\text { CL } \\
288\end{array}$} & \multirow{2}{*}{$\begin{array}{l}\text { EP 3 } \\
1.65\end{array}$} & \multicolumn{2}{|c|}{ SK } & \multirow{2}{*}{$\begin{array}{c}\mathrm{CL} \\
288\end{array}$} & \multirow{2}{*}{$\begin{array}{c}\text { CJ } \\
1.44\end{array}$} & \multirow{2}{*}{$\begin{array}{c}\text { SK } \\
\text { A }\end{array}$} \\
\hline 166 & 1.24 & $A$ & $\mathrm{a}$ & & & $A$ & $\mathrm{a}$ & & & A & $\mathrm{a}$ & & & \\
\hline 280 & 1.11 & $A$ & $\mathrm{a}$ & 201 & 1.38 & A & $\mathrm{a}$ & 166 & 1.47 & A & a & 166 & 1.39 & A \\
\hline 201 & 1.11 & $A$ & $\mathrm{a}$ & 49 & 1.37 & A & a & 251 & 1.45 & A & $\mathrm{a}$ & 5 & 1.31 & A \\
\hline 251 & 1.10 & $A$ & $\mathrm{a}$ & 80 & 1.34 & A & a & 5 & 1.43 & $A$ & $a$ & 251 & 1.27 & A \\
\hline 80 & 1.09 & A & $\mathrm{a}$ & 280 & 1.29 & A & a & 80 & 1.39 & A & a & 80 & 1.22 & B \\
\hline 70 & 1.08 & $A$ & $\mathrm{a}$ & 288 & 1.24 & A & $\mathrm{a}$ & 49 & 1.29 & A & $\mathrm{a}$ & 280 & 1.21 & B \\
\hline 5 & 1.08 & $A$ & $\mathrm{a}$ & 251 & 1.23 & A & $\mathrm{a}$ & 280 & 1.23 & A & $\mathrm{a}$ & 70 & 1.14 & B \\
\hline IAC 8 & 1.07 & $A$ & $\mathrm{a}$ & 147 & 1.20 & A & $\mathrm{a}$ & IAC 2 & 1.21 & A & $a$ & IAC 8 & 1.14 & B \\
\hline 49 & 0.98 & $A$ & $\mathrm{a}$ & 70 & 1.12 & A & a & 201 & 1.20 & A & $\mathrm{a}$ & 49 & 1.09 & B \\
\hline 288 & 0.96 & $A$ & $\mathrm{a}$ & 5 & 1.09 & A & $\mathrm{a}$ & IAC 8 & 1.18 & A & $\mathrm{a}$ & 201 & 1.08 & B \\
\hline 147 & 0.94 & $A$ & $\mathrm{a}$ & IAC 8 & 0.98 & A & b & 137 & 1.17 & A & a & IAC 2 & 1.07 & B \\
\hline IAC 2 & 0.89 & $A$ & $\mathrm{a}$ & 146 & 0.97 & A & b & 70 & 1.16 & A & $\mathrm{a}$ & 144 & 1.05 & B \\
\hline 144 & 0.87 & $A$ & $\mathrm{a}$ & 144 & 0.97 & A & b & 144 & 1.07 & A & $\mathrm{a}$ & 137 & 1.03 & B \\
\hline 146 & 0.79 & A & $b$ & IAC 2 & 0.94 & A & b & 2 & 1.00 & A & $b$ & 2 & 0.93 & $C$ \\
\hline 135 & 0.78 & $A$ & $b$ & 137 & 0.92 & A & b & 22 & 0.96 & A & $b$ & 9 & 0.91 & $C$ \\
\hline 22 & 0.76 & $A$ & $b$ & 128 & 0.91 & A & b & 128 & 0.96 & A & b & 128 & 0.90 & $C$ \\
\hline 2 & 0.75 & $A$ & $b$ & 135 & 0.88 & A & b & 9 & 0.95 & A & b & 22 & 0.89 & $C$ \\
\hline 120 & 0.74 & $A$ & $b$ & 9 & 0.86 & A & b & 146 & 0.93 & A & b & 146 & 0.83 & $C$ \\
\hline 128 & 0.74 & $A$ & $b$ & 22 & 0.82 & A & b & 199 & 0.86 & A & b & 135 & 0.81 & $C$ \\
\hline 137 & 0.72 & $A$ & $b$ & 2 & 0.78 & A & b & 129 & 0.82 & A & b & 147 & 0.79 & $C$ \\
\hline 129 & 0.68 & $A$ & $b$ & 120 & 0.77 & A & b & 147 & 0.81 & A & b & 199 & 0.77 & $C$ \\
\hline 9 & 0.67 & $A$ & $b$ & 129 & 0.73 & A & $b$ & 241 & 0.77 & A & $b$ & 129 & 0.76 & $C$ \\
\hline 212 & 0.56 & $A$ & c & 235 & 0.69 & A & c & 135 & 0.74 & A & b & 120 & 0.70 & $\mathrm{D}$ \\
\hline 235 & 0.53 & $A$ & $c$ & 238 & 0.66 & A & c & 120 & 0.73 & A & $b$ & 241 & 0.68 & D \\
\hline 109 & 0.50 & $A$ & $c$ & 109 & 0.65 & A & c & 109 & 0.70 & A & b & 109 & 0.63 & $D$ \\
\hline 199 & 0.47 & $A$ & $c$ & 199 & 0.64 & A & c & 238 & 0.68 & A & $b$ & 212 & 0.62 & D \\
\hline 241 & 0.43 & $A$ & $c$ & 212 & 0.58 & A & c & 44 & 0.63 & A & b & 44 & 0.60 & D \\
\hline 44 & 0.36 & $A$ & c & 241 & 0.44 & A & c & 212 & 0.62 & A & $b$ & 235 & 0.53 & D \\
\hline 219 & 0.35 & $A$ & c & 219 & 0.35 & A & c & 235 & 0.57 & A & b & 219 & 0.53 & D \\
\hline 238 & 0.33 & $B$ & c & 44 & 0.35 & A & c & 219 & 0.54 & A & $b$ & 238 & 0.52 & $\mathrm{D}$ \\
\hline Means & 0.76 & $C$ & & & 0.89 & B & & & 0.98 & A & & & 0.93 & \\
\hline CV(\%) & 8.48 & & & & 8.92 & & & & 9.47 & & & & 9.50 & \\
\hline
\end{tabular}

Means followed by the same minuscule letter (vertical) do not differ significantly between clones by Scott and Knott test (SK) at $5 \%$ of probability.

Means followed by the same capital letter (horizontal) do not significantly differ between experiments by Scott and Knott test (SK) at $5 \%$ of probability.

${ }^{*} \mathrm{CL}=$ clones: $\mathrm{CJ}=$ joint analysis of experiments: $\mathrm{CV}(\%)=$ environmental coefficient of variation: $\mathrm{EP} 1=$ first experiment: $\mathrm{EP} 2=$ second experiment: $\mathrm{EP} 3=$ third experiment. 
Table 3. Evaluation of oil production per plant (OPP) in 28 experimental clones and two control clones in Lippia alba

\begin{tabular}{|c|c|c|c|c|c|c|c|c|c|c|c|c|c|c|}
\hline \multicolumn{15}{|c|}{ Clones and experiments* } \\
\hline CL & EP 1 & \multicolumn{2}{|c|}{ SK } & \multirow{2}{*}{$\begin{array}{c}\text { CL } \\
280\end{array}$} & \multirow{2}{*}{$\begin{array}{c}\text { EP } 2 \\
2.3632\end{array}$} & \multicolumn{2}{|c|}{ SK } & \multirow{2}{*}{$\begin{array}{l}\text { CL } \\
280\end{array}$} & \multirow{2}{*}{$\begin{array}{c}\text { EP } 3 \\
1.6344\end{array}$} & \multicolumn{2}{|c|}{ SK } & \multirow{2}{*}{$\begin{array}{c}\mathrm{CL} \\
280\end{array}$} & \multirow{2}{*}{$\begin{array}{c}\text { CJ } \\
1.4100\end{array}$} & \multirow{2}{*}{$\begin{array}{c}\text { SK } \\
\text { A }\end{array}$} \\
\hline IAC 8 & 0.2495 & A & a & & & A & $\mathrm{a}$ & & & $A B$ & $\mathrm{a}$ & & & \\
\hline 280 & 0.2325 & B & $\mathrm{a}$ & IAC 2 & 1.2646 & $A$ & $b$ & iAC 8 & 0.8820 & $A$ & $b$ & IAC 2 & 0.7586 & $\mathrm{~B}$ \\
\hline 166 & 0.1863 & A & b & IAC 8 & 1.0345 & $A$ & $b$ & iAC 2 & 0.8288 & $A B$ & $b$ & IAC 8 & 0.7220 & $\mathrm{~B}$ \\
\hline IAC 2 & 0.1826 & B & $b$ & 166 & 0.9649 & A & $b$ & 288 & 0.6395 & $A$ & c & 251 & 0.5625 & C \\
\hline 201 & 0.1479 & A & $b$ & 251 & 0.9243 & $A$ & $b$ & 251 & 0.6332 & $A$ & c & 166 & 0.5429 & $C$ \\
\hline 144 & 0.1367 & A & b & 288 & 0.8629 & $A$ & $b$ & 70 & 0.5109 & B & $d$ & 288 & 0.5266 & $C$ \\
\hline 147 & 0.1322 & C & b & 201 & 0.8581 & $A$ & $b$ & 238 & 0.4833 & $A$ & d & 201 & 0.4543 & $C$ \\
\hline 251 & 0.1300 & B & b & 80 & 0.7990 & A & $b$ & 166 & 0.4776 & $A$ & d & 70 & 0.4415 & $C$ \\
\hline 70 & 0.1086 & C & c & 144 & 0.7706 & $A$ & $b$ & 5 & 0.4078 & $A$ & $d$ & 238 & 0.3805 & $C$ \\
\hline 5 & 0.1016 & A & c & 70 & 0.7051 & $A$ & $b$ & 199 & 0.3649 & $A$ & e & 80 & 0.3615 & $C$ \\
\hline 238 & 0.0995 & A & c & 137 & 0.6371 & A & $c$ & 201 & 0.3569 & $A$ & e & 144 & 0.3568 & $C$ \\
\hline 9 & 0.0926 & B & c & 128 & 0.6220 & $A$ & $c$ & 137 & 0.3381 & $A$ & e & 147 & 0.3507 & $C$ \\
\hline 120 & 0.0921 & B & c & 135 & 0.6161 & $A$ & $c$ & 146 & 0.3344 & $A B$ & e & 137 & 0.3430 & $C$ \\
\hline 135 & 0.0901 & B & c & 147 & 0.6006 & $A$ & $c$ & 147 & 0.3194 & $B$ & e & 129 & 0.3173 & $C$ \\
\hline 109 & 0.0805 & $C$ & c & 129 & 0.5914 & $A$ & $c$ & 129 & 0.3192 & $A$ & $\mathrm{e}$ & 128 & 0.3077 & $C$ \\
\hline 80 & 0.0805 & A & c & 9 & 0.5898 & $A$ & $c$ & 219 & 0.3106 & $A$ & e & 49 & 0.2988 & $C$ \\
\hline 288 & 0.0773 & B & c & 49 & 0.5709 & A & $c$ & 241 & 0.2846 & $A$ & $\mathrm{e}$ & 135 & 0.2927 & $C$ \\
\hline 199 & 0.0720 & A & c & 238 & 0.5587 & $A$ & $c$ & 109 & 0.2844 & B & e & 199 & 0.2862 & $C$ \\
\hline 49 & 0.0591 & A & c & 109 & 0.4638 & $A$ & $c$ & 2 & 0.2768 & $A$ & $\mathrm{e}$ & 5 & 0.2805 & $C$ \\
\hline 219 & 0.0569 & B & c & 146 & 0.4434 & $A$ & $c$ & 49 & 0.2664 & $A$ & e & 9 & 0.2794 & $C$ \\
\hline 22 & 0.0561 & A & c & 199 & 0.4217 & A & $c$ & 128 & 0.2561 & $B$ & $\mathrm{e}$ & 109 & 0.2762 & $C$ \\
\hline 241 & 0.0551 & A & c & 219 & 0.4048 & $A$ & $c$ & 44 & 0.2532 & $A$ & $\mathrm{e}$ & 146 & 0.2726 & $C$ \\
\hline 137 & 0.0538 & A & c & 120 & 0.3662 & $A$ & $c$ & 80 & 0.2051 & $A$ & e & 219 & 0.2574 & $C$ \\
\hline 235 & 0.0503 & A & c & 241 & 0.3411 & $A$ & $c$ & 22 & 0.2011 & $A$ & e & 241 & 0.2269 & $C$ \\
\hline 2 & 0.0471 & B & c & 235 & 0.3333 & $A$ & $c$ & 120 & 0.1854 & $A B$ & $\mathrm{e}$ & 120 & 0.2146 & $C$ \\
\hline 128 & 0.0452 & B & c & 5 & 0.3321 & A & $c$ & 212 & 0.1851 & $A$ & e & 2 & 0.2010 & $C$ \\
\hline 212 & 0.0420 & A & c & 2 & 0.2790 & $A$ & $c$ & 135 & 0.1721 & B & $\mathrm{e}$ & 235 & 0.1818 & $C$ \\
\hline 129 & 0.0413 & A & c & 212 & 0.2570 & $A$ & $c$ & 144 & 0.1632 & $A$ & $\mathrm{e}$ & 22 & 0.1656 & $C$ \\
\hline 146 & 0.0400 & B & c & 22 & 0.2397 & A & $c$ & 235 & 0.1620 & $A$ & $\mathrm{e}$ & 212 & 0.1614 & $C$ \\
\hline 44 & 0.0257 & B & c & 44 & 0.2007 & $A$ & $c$ & 9 & 0.1558 & $B$ & $\mathrm{e}$ & 44 & 0.1598 & $C$ \\
\hline Means & 0.0955 & C & & & 0.6472 & A & & & 0.3964 & B & & & 0.3796 & \\
\hline CV(\%) & 29.29 & & & & 36.11 & & & & 20.30 & & & & 37.82 & \\
\hline
\end{tabular}

Means followed by the same minuscule letter (vertical) do not differ significantly between clones by Scott and Knott test (SK) at $5 \%$ of probability.

Means followed by the same capital letter (horizontal) do not significantly differ between experiments by Scott and Knott test (SK) at $5 \%$ of probability.

${ }^{*} \mathrm{CL}=$ clones: $\mathrm{CJ}=$ joint analysis of experiments: $\mathrm{CV}(\%)=$ environmental coefficient of variation: $\mathrm{EP} 1=$ first experiment: $\mathrm{EP} 2=$ second experiment: $\mathrm{EP} 3=$ third experiment.

Table 4. Linalool percentage of the five Lippia alba clones recombinants with higher leaf dry matter compared with two controls based on results of three experiments; Tukey's test at $5 \%$ for individual and joint variance analysis

\begin{tabular}{|c|c|c|c|c|c|c|c|c|c|c|c|c|c|c|}
\hline \multicolumn{15}{|c|}{ Clones and experiments* } \\
\hline CL & EP 1 & \multicolumn{2}{|c|}{ Tk } & \multirow{2}{*}{$\begin{array}{c}\text { CL } \\
288\end{array}$} & \multirow{2}{*}{$\begin{array}{l}\text { EP } 2 \\
84.48\end{array}$} & \multicolumn{2}{|c|}{ Tk } & \multirow{2}{*}{$\begin{array}{l}\text { CL } \\
288\end{array}$} & \multirow{2}{*}{$\begin{array}{r}\text { EP } 3 \\
84.48\end{array}$} & \multicolumn{2}{|c|}{ Tk } & \multirow{2}{*}{$\begin{array}{l}\text { CL } \\
201\end{array}$} & \multirow{2}{*}{$\begin{array}{c}\text { CJ } \\
85.28\end{array}$} & \multirow{2}{*}{$\begin{array}{c}\text { Tk } \\
\text { A }\end{array}$} \\
\hline 201 & 87.02 & $A$ & $\mathrm{a}$ & & & A & $\mathrm{a}$ & & & A & $\mathrm{a}$ & & & \\
\hline 251 & 85.81 & $A$ & $\mathrm{a}$ & 201 & 84.38 & A & a & 201 & 84.38 & $A$ & a & 288 & 84.82 & A \\
\hline 288 & 85.51 & A & a & 251 & 81.94 & B & $b$ & 251 & 81.94 & B & b & 251 & 83.27 & $A B$ \\
\hline IAC 8 & 83.12 & $A$ & $\mathrm{a}$ & 280 & 79.84 & $\mathrm{BC}$ & $\mathrm{a}$ & 280 & 79.84 & $\mathrm{BC}$ & $\mathrm{a}$ & IAC 8 & 80.76 & $\mathrm{BC}$ \\
\hline IAC 2 & 79.00 & $A$ & $\mathrm{a}$ & $\mathrm{iAC} 8$ & 79.55 & C & a & iAC 8 & 79.55 & $C$ & $\mathrm{a}$ & 280 & 79.38 & $C$ \\
\hline 280 & 78.46 & A & a & $\mathrm{i} A C 2$ & 77.03 & $\mathrm{D}$ & a & $\mathrm{I} A C 2$ & 77.03 & D & $a$ & $\mathrm{I} A C 2$ & 77.69 & $C D$ \\
\hline 166 & 75.51 & $A$ & $\mathrm{a}$ & 166 & 73.47 & $\mathrm{E}$ & a & 166 & 73.47 & $E$ & $\mathrm{a}$ & 166 & 74.15 & $\mathrm{D}$ \\
\hline Means & 82.24 & & $\mathrm{a}$ & & 80.22 & & b & & 80.22 & & $b$ & & 64.09 & \\
\hline CV(\%) & 3.45 & & & & 0.60 & & & & 0.59 & & & & 2.08 & \\
\hline
\end{tabular}

Means followed by the same minuscule letter (vertical) do not differ significantly between clones by Tukey's test (Tk) at $5 \%$ of probability.

Means followed by the same capital letter (horizontal) do not significantly differ between experiments by Tukey's test (Tk) at $5 \%$ of probability.

${ }^{*} \mathrm{CL}=$ clones: $\mathrm{CJ}=$ joint analysis of experiments: $\mathrm{CV}(\%)=$ environmental coefficient of variation: $\mathrm{EP} 1$ = first experiment: $\mathrm{EP} 2=$ second experiment: $\mathrm{EP} 3=$ third experiment. 


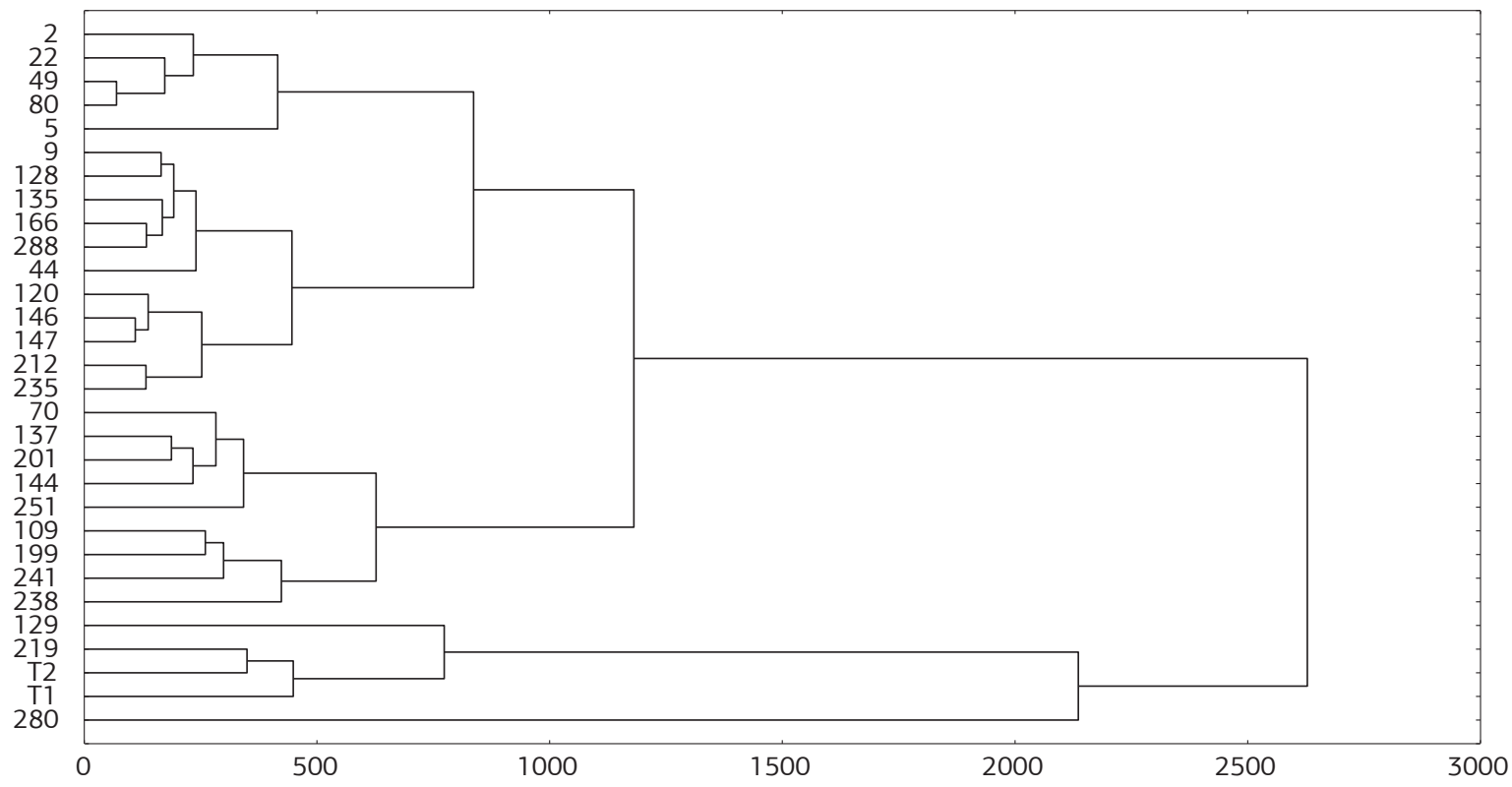

Figure 1. Genetic divergence analysis for 30 Lippia alba clones. Genetic distances were obtained from means of three experiments and were quantified by standardized Euclidean distance; clustering was made by the UPGMA method. T1: the best control IAC 2; T2: the best control IAC 8 .

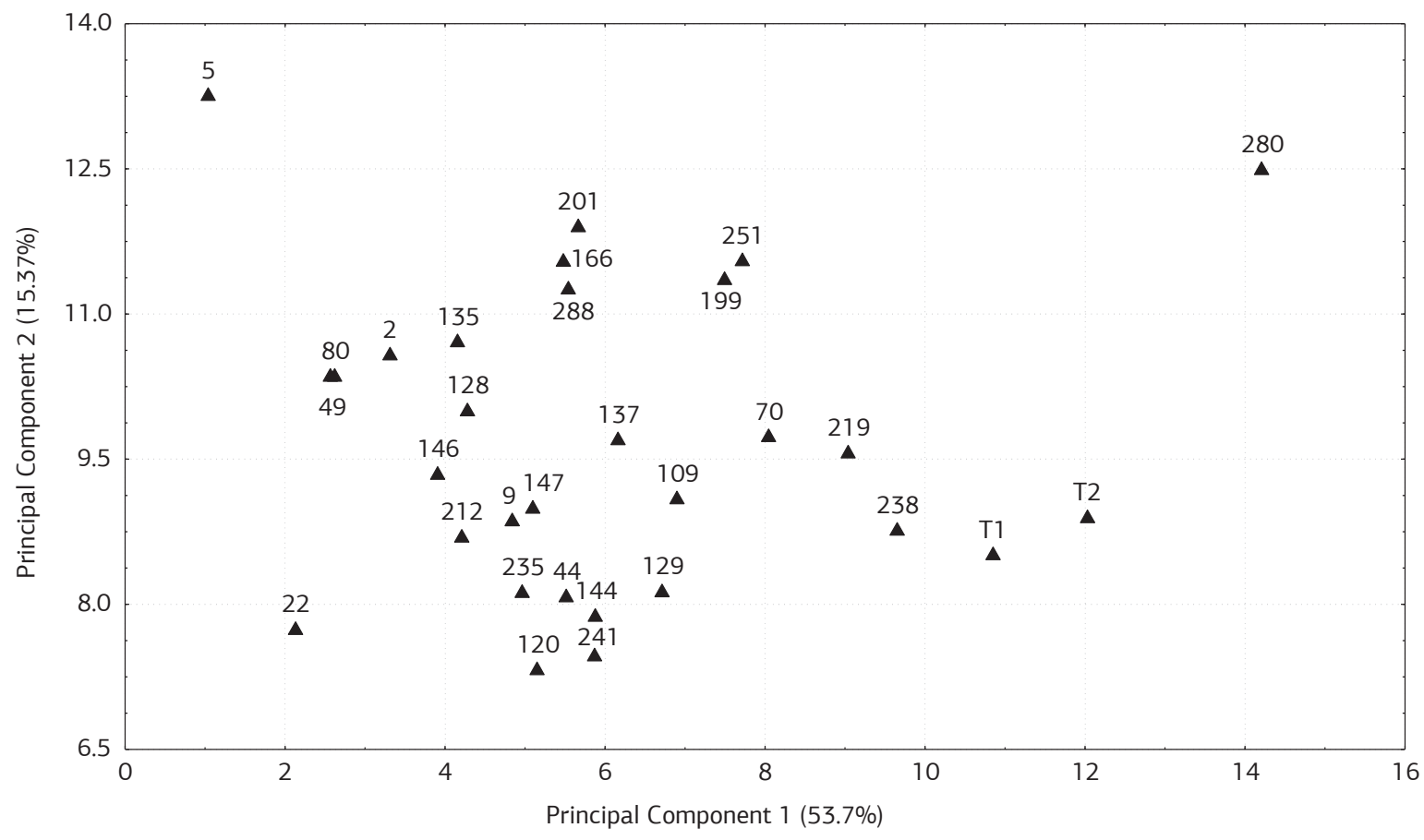

Figure 2. Principal components analysis (PCA1 and PCA2) for thirty Lippia alba clones based on studied traits and means from three experiments. T1: the best control IAC 2; T2: the best control IAC 8. 


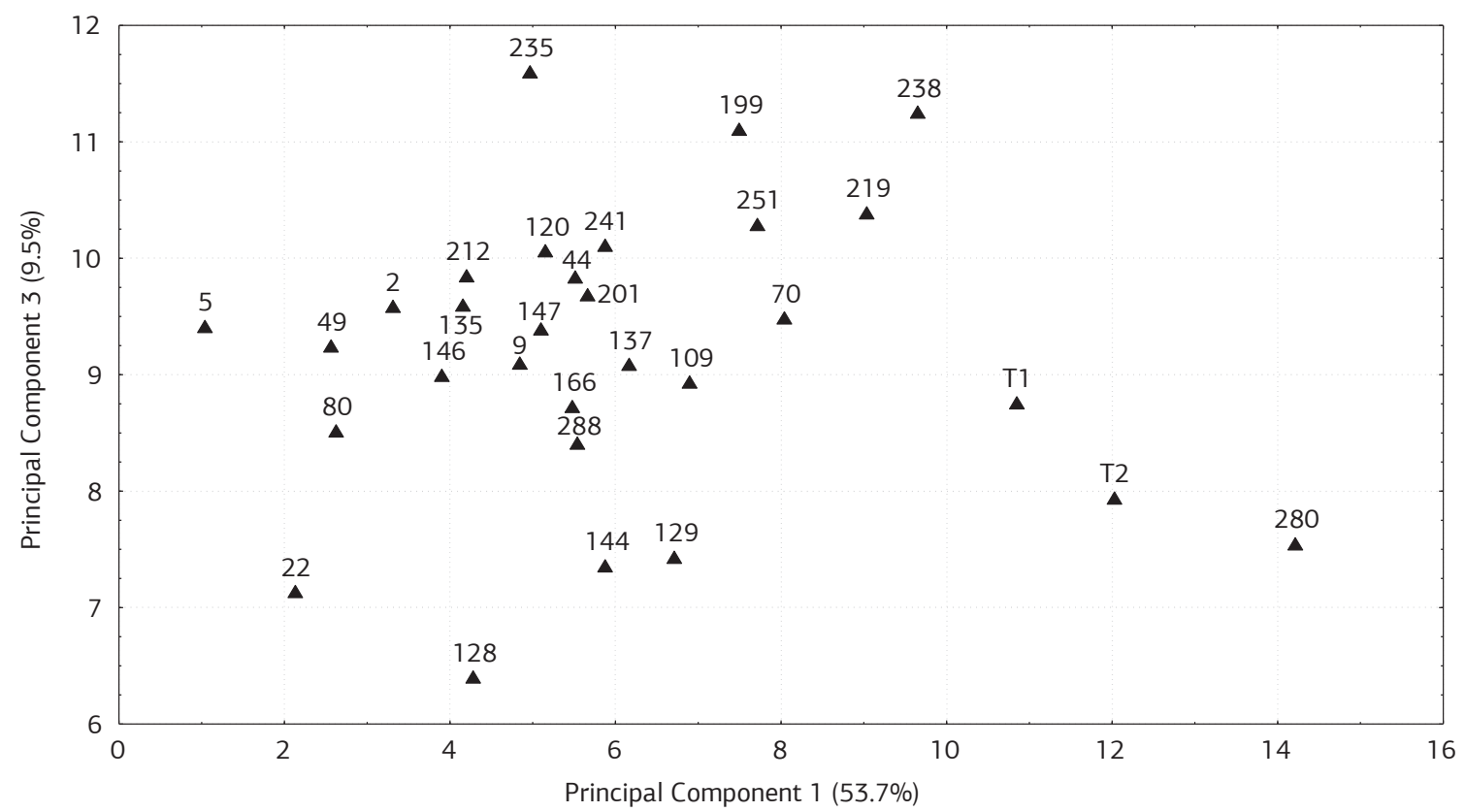

Figure 3. Principal components analysis (PCA1 and PCA3) for thirty Lippia alba clones based on studied traits and means from three experiments. T1: the best control IAC 2; T2: the best control IAC 8.

\section{CONCLUSION}

The clone 280 from two recombinations was higher than controls for most traits, including dry mass leaves (DML) and oil production per plant (OPP).

It was obtained within the clones evaluated, an individual "off type" (clone 201) for the characters of dry mass leaves, LN\%, and this clone does not follow the trend established for this correlation variables.

Two clones were selected with higher production of linalool per plant: clone 201 (85.3\%) and 251 (84.1\%).

\section{REFERENCES}

ADAMS, R.P.L. Identification of essential oil components by gas chromatography/mass spectroscopy. Carol Stream: Allured Publishing, 1995. 469p.

ATTI-SERAFINI, L.; PANSERA, M.R.; ATTI-SANTOS, A.C.; ROSSATO, M.; PAULETTI, G.F.; ROTA, L.D.; PAROUL, N.; MOYNA, P. Variation in essential oil yield and composition of Lippia alba (Mill) N. E. Br. grown in southern Brazil. Revista Brasileira de Plantas Medicinais, v.4, p.72-74, 2002.

BOZIN, B.; DUKIC, N.M.; SIMIN, N.; ANACKOV, G. Caracterization of the volite conposition of essential oils of some Laminace species and the antimicrobial and antioxidant activities of the entire oils. Journal of Agricultural and Food Chemistry, v.54, p.1822-1828, 2006.
BRAGA, M.E.M.; EHLERT, A.D.; MING, L.C.; MEIRELES, M.A.A. Supercritical fluid extraction from Lippia alba global yields, kinetic data, and extract composition. The Journal of Supercritical Fluids, v.34, p.149-156, 2005.

BRANDÃO, A.D.; VICCINI, L.F.; SALIMENA, F.R.G.; VANZELA, A.L.L.; PIMENTEL, S.M.R. Cytogenetic characterization of Lippia alba and Lantana câmara (Verbenaceae) from Brazil. Journal of Plant Resources, v.120, p.317-321, 2007.

CARVALHO, A.C.B.; BALBINO, E.E.; MACIEL, A.; PERFEITO, J.P.S. Situação do registro de medicamentos fitoterápicos no Brasil. Revista Brasileira de Farmacognosia, v.18, p.314-319, 2008.

CRUZ, C.D. Princípios de genética quantitativa. Viçosa: UFV, 2005.394p.

CRUZ, C.D. Programa Genes - Versão Windows. Viçosa: UFV, 2001.

DI STASI, L.C.; OLIVEIRA, G.P.; CARVALHAES, M.A.; QUERIROZ-JUNIOR, M.; TIEN, O.S.; KAKINAMI, S.H. Medicinal plants popularly used in the brazilian tropical atlantic forest. Fitoterapia, v.73, p.69-91, 2002.

GAZOLA, R.; MACHADO, D.; RUGGIERO, C.; SING, G.; ALEXANDRE, M.M. Lippia alba, Melissa oficinalis and Cymbopogon citratus: effects of the aqueous estracts on the isolated hearts of rats. Pharmacological Research, v.50, p.477-480, 2004.

GOMES, F.P. Curso de estatística experimental. 3.ed. Piracicaba: Universidade São Paulo, Escola Superior de Agricultura Luis de Queiroz, 1966. 205p. 
JULIÃO, L.S.; TAVARES, E.S.; LAGE, C.L.S.; LEITÁO, S.G. Cromatografia em camada fina de extratos de três quimiótipos de Lippia alba (Mill) N.E.Br. (erva cidreira). Revista Brasileira de Farmacognosia, v.13, p.36-38, 2003.

LUZ, J.M.Q.; MORAIS, T.P.S.; BLANK, A.F.; SODRÉ, A.C.B.; OLIVEIRA, G.S. Teor, rendimento e composição química do óleo essencial de manjericáo sob doses de cama de frango. Horticultura Brasileira, v.27, p.349-353, 2009.

MACHADO, A.A.; ZONTA, E.P. Manual do SANEST: Sistema de análise estatística para microcomputadores. Pelotas: Universidade Federal de Pelotas, 1995.

MARCO, C.A.; INNECCO, R.; MATTOS, S.H.; BORGES, N.S.S.; FILHO, S.M. Influencia de espaçamento, altura e época de corte no rendimento da biomassa e óleo essencial na cultura de capim citronela (Cymbopogon vinterianus Jowitt). Revista Ciência Agronômica, v.37, p.32-36, 2006.

MARTINS, A.G.L.A.; NASCIMENTO, A.R.; FILHO, J.E.M.; MENDES FILHO, N.E.; SOUZA, A.G.; ARAGÃO, N.E.; SILVA, D.S.V. Atividade antimicrobiana do óleo essencial do manjericão frente a sorogrupos de Escherichia colli enteropatogênica isolados de alfaces. Ciência Rural, v.40, p.1791-1796, 2010.

MORRISON, DF. Multivariate statistical methods. McGraw-Hill, New York, 1976. 222p.

RUFINO, E.R.; SIQUEIRA, W.J.; MARQUEZ, M.O.M.; COLOMBO, C.A.; CHIORATO, A.F.; AZEVEDO FILHO, J.A.; LOURENÇÃO, A.L.; YAMAMOTO, P.Y; MARTINS, A.L.M. Estimativas de parâmetros genéticos de caracteres relacionados ao vigor de estacas em Lippia alba. Bragantia, v.69, p.779-785, 2010.

SANGALLI, A.; VIEIRA, M.C.; ZÁRDE, N.A.H. Resíduos orgânicos e nitrogênio na produção de biomassa da capuchinha (Trapoelum majes L.) 'Jewel'. Ciência e Agrotecnologia, v.28, p.831-839, 2004.

SANTOS, M.R.A.; INNECCO, R. Influência de períodos de secagem de folhas no óleo essencial de erva cidreia (quimiótipo limoneno-carvona). Revista Ciência Agronômica, v.34, p.5-11, 2003.

SCARPA, G.F. Medicinal plants used by the criollos of northwestern Argentine Chaco. Journal Ethnopharmacology, v.91, p.115-135, 2004.
SCOTT, A.J.; KNOTT, M.A. A cluster analysis method for grouping means in the analysis of variance. Biometrics, v.30, p.507512,1974

SHIMAKURA, S.E.; RIBEIRO JÚNIOR, P.J. Statistics: chapter 8, sub chapter 8.3: Descriptive statistics: interpretation of the correlation coefficient. Statistics Department, UFPR, 2007. Available at: http://leg.ufpr.br/ paulojus/CE003/ce003/node8. html 2007 Acessed: Jan./ 2009.

SILVA, D.D.; CHIERICE, G.O.; GALHIANE, M.S.; CHAAR, J.S.; FILHO, V.E.M. Quantificação do linalol no óleo essencial da Aniba dukei Korstermans utilizando uma nova coluna capilar polhyh4-md em cromatografia gasosa. Química Nova, v.26, p.461$465,2003$.

SILVA, N.A.; OLIVEIRA, F.F.; COSTA, L.C.B.; BIZZO, H.R.; OLIVEIRA, R.A. Caracterização química do óleo essencial da erva cidreira (Lippia alba Mill N.E.BR) cultivada em Ilhéus na Bahia. Revista Brasileira de Plantas Medicinais, v.8, p.52-55, 2006.

SIMÓES, C.M.O.; SPITZER, V. Óleos voláteis. In Simôes, C.M.O Farmacognesia da planta ao medicamento. 5.ed, Porto Alegre: UFRGS/UFSC. 2003. p.467-495.

STATSOFT INC. Statistica 6 for Windows. 1999. Available from: http://www.statsoft.com.

TAVARES, E.S.; JULIÃO, L.S.; LOPES, D.; BIZZO, H.R.; LAGE, C.L.S.; LEITÃO, S.G. Análise do óleo essencial de folhas de três quimiótipos de Lippia alba (Mill) N.E.Br (Verbenaceae) cultivados em condiçôes semelhantes. Revista Brasileira de Farmacognosia, v.1, p.1-5, 2005.

VAN DEN DOOL, H.; KRATZ, D.J.A. Generalization of the retention index system including liner temperature programmed gas-liquid partition chromatography. Journal Chromatography, v.11, p.463-467, 1963.

YAMAMOTO, P.Y.; COLOMBO, C.A.; AZEVEDO FILHO, J.A.; LOURENÇÃO, A.L.; MARQUES, M.O.M.; MORAIS, G.D.S.; CHIORATO, A.F., MARTINS, A.L.M.; SIQUEIRA, W.J. Performance of ginger grass (Lippia alba) for traits related to the production of essential oil. Scientia Agricola, v.65, p.481-489, 2008.

ZIMMERMANN, F.J.P. Estatística aplicada à pesquisa agrícola. Santo Antônio de Goiás: Embrapa Arroz e Feijão, 2004. p. 25-48. 